\title{
POLA SEBARAN AIR LINDI DI TPA BATU LAYANG PONTIANAK DENGAN METODE GEOLISTRIK WENNER-SCHLUMBERGER
}

Eza Rizky Apriasti ${ }^{11}$, Marsudi2), Kiki Prio Utomo ${ }^{1)}$

1) Program Studi Teknik Lingkungan Jurusan Teknik Sipil Fakultas Teknik Universitas Tanjungpura, Pontianak

2) Program Studi Teknik Sipil Jurusan Teknik Sipil Fakultas Teknik Universitas Tanjungpura, Pontianak Email : ezarapriasti@gmail.com

\begin{abstract}
ABSTRAK
TPA Batu Layang merupakan Tempat Pemrosesan Akhir Sampah di Pontianak yang menggunakan sistem open dumping. Lindi yang dihasilkan dari penumpukan sampah di sel TPA berpotensi mencemari lingkungan dan air tanah di areal TPA. Untuk itu perlu dilakukan penelitian di TPA Batu Layang dengan tujuan untuk mengetahui daerah sebaran air lindi. Pendugaan sebaran air lindi di bawah permukaan tanah dilakukan dengan metode geolistrik tahanan jenis konfigurasi Wenner-Schlumberger dengan menggunakan nilai dugaan resistivitas lindi dibawah $10 \mathrm{ohm} . \mathrm{m}$ Penelitian ini menggunakan 4 lintasan, lintasan 1 berada pada sel TPA Batu layang yang sudah tidak aktif lagi. Lintasan ini digunakan sebagai kontrol. Lintasan lainnya berada diwilayah selatan TPA Batu Layang. Pemilihan wilayah selatan ini dikarenakan wilayah ini dekat dengan pemukiman penduduk. Hasil penelitian ini menunjukkan adanya dugaan lindi dimasing-masing lintasan dengan nilai RMSE diatas $10 \%$, nilai ini tidak dapat mewakili kondisi sebenarnya di lapangan. Pada Lintasan 1 nilai RMSE sebesar 33,9\%, dugaan lindi berada pada jarak 4,5 - 37,5 m dengan kedalaman 4,06 m. Lintasan 2, nilai RMSE 38,6\% dengan dugaan lindi terdapat pada jarak $6-10,5 \mathrm{~m}$ dengan kedalaman mencapai 2,74 m. Dugaan lindi pada lintasan 3 terdapat pada pada jarak 5,25-37,5 m dengan kedalaman sebaran dugaan lindi mencapai 5,9 m dan nilai RMSE 35,2\%. Lintasan 4 dugaan lindi berada pada jarak $9-36 \mathrm{~m}$ dengan kedalaman 4,06 m dan nilai RMSE 41,5\%. Dugaan lindi mengalir ke arah selatan dan sebarannya mencapai ke pemukiman penduduk sejauh $156 \mathrm{~m}$ dari TPA Batu Layang.
\end{abstract}

Kata Kunci : Geolistrik Resistivitas, Konfigurasi Wenner-Schlumberger, TPA Batu Layang

\begin{abstract}
TPA Batu Layang is a landfill located in Pontianak which uses open dumping system, leachate that caused from the accumulation of garbage in the landfill cell potencially pollutes the environment and groundwater in the area of landfill. So, research is necessarily to be conducted in TPA Batulayang in order to determine the distribution of leachate area. Estimation of water distribution in the leachate subsurface used resistivity geoelectric method with WennerSchlumberger configuration using leachat resistivity alleged value below $10 \mathrm{ohm}$. The research uses 4 track, one track is located at Batu Layang landfill cells that are no longer active. The track is used as a control. The other tracks are in the south of TPA Batu Layang. The results showed the leachate alleged in each track with the value of RMSE above 10\%, this value may not represent actual field conditions. On track 1 the leachate alleged as far as 4,5-37,5 $\mathrm{m}$ with depth of 4,06 $\mathrm{m}$ with the value of RMSE 33,9\%. The leachate alleged on track 2 as far as $6-10,5 \mathrm{~m}$ with depth of $2,74 \mathrm{~m}$ and the value of RMSE $38,6 \%$. The leachate alleged on track 3 which is located at a distance of 5,25 - 37,5 $\mathrm{m}$ with depth of alleged leachate distribution 5,9 $\mathrm{m}$ and RMSE 35,2\%. On tracks 4 the leachate alleged as far as 9-36 $\mathrm{m}$ with depth of 4,06 $\mathrm{m}$ and the value of RMSE 41,5\%. The leachate alleged flowing to south and its distribution reach to $156 \mathrm{~m}$ settlement of TPA Batu Layang.
\end{abstract}

Keywords: Resistivity Geolectric, Wenner-Schlumberger Configuration, TPA of Batu Layang 


\section{PENDAHULUAN}

Sampah merupakan permasalahan yang sering ditemui di kota besar di Indonesia. Menurut Wardhana (1995) meningkatnya populasi manusia menyebabkan pencemaran air permukaan dan air tanah cenderung meningkat terutama yang disebabkan oleh penumpukan sampah sehingga dapat menganggu kesehatan masyarakat. Sampah yang menumpuk memiliki dampak negatif bagi lingkungan. Salah satu cara yang dilakukan dalam menangani permasalahan sampah adalah dengan mengelola sampah secara komunal di Tempat Pemrosesan Akhir (TPA).

Kota Pontianak memiliki TPA yang berada di wilayah Kecamatan Pontianak Utara tepatnya di Kelurahan Batu Layang. TPA tersebut masih menerapkan sistem open dumping dimana sampah akan ditumpuk dengan ketinggian tertentu di setiap sel dan akan ditutup dengan tanah penutup.

Berdasarkan data dari Dinas Kebersihan dan Pertamanan Kota Pontianak volume timbulan sampah yang masuk ke TPA Batu Layang tahun 2015 yaitu 1.286,3 $\mathrm{m}^{3} /$ hari dan komposisi sampah yang masuk ke TPA $83 \%$ terdiri dari sampah organik dan $17 \%$ terdiri dari sampah non organik. Sebagian besar sampah organik yang masuk ke TPA berasal dari sampah rumah tangga dan pasar. Sampah organik apabila dibiarkan menumpuk dalam waktu yang cukup lama akan terdekomposisi menghasilkan leachate (lindi). Lindi yang berasal dari sampah perkotaan terdiri dari senyawa anorganik, logam, dan senyawa organik yang bersifat biodegradable seperti selulosa, lignin, hemiselulosa, dan protein (Iqbal dan Gupta, 2009).

Berdasarkan hasil penelitian yang dilakukan oleh Suwendi (2011) air tanah di wilayah TPA Batu Layang mengandung logam berat Kadmium (Cd) sebesar 1,1667 mg/l. Hal ini menunjukan bahwa air tanah di wilayah tersebut telah tercemar karena konsentrasi Kadmium berada diatas baku mutu yang diizinkan 0,01 mg/l. Menas Aswan (2014) juga melakukan penelitian mengenai rembesan polutan di TPA Batu Layang dengan menggunakan EM-Conductivity, ditemukannya dugaan rembesan polutan yang menyebar dari arah utara ke selatan sejauh $\mathbf{7 4}$ meter. Untuk itu perlu dilakukannya penelitian ini karena belum adanya data yang menunjukan daerah dampak sebaran air lindi yang merembes dari TPA Batu Layang menggunakan metode geolistrik Wenner-Shclumberger dengan memanfaatkan nilai resistivitas dugaan air lindi yang berada dibawah $10 \mathrm{ohm}$.

\section{METODOLOGI PENELITIAN}

\section{A. LOKASI DAN WAKTU PENELITIAN}

Penelitian dilaksanakan di wilayah selatan TPA Batu Layang Pontianak. Waktu yang dibutuhkan untuk melakukan rangkaian kegiatan penelitian ini adalah selama 4 bulan terhitung dari bulan September hingga bulan Desember 2015.

\section{B. ALAT}

Alat-alat yang digunakan dalam penelitian ini adalah batang besi sebagai elektroda, kabel penghubung antara elektroda dan alat resistivitymeter, aki, software Res2Dinv, pita ukur, Global Positioning System (GPS) dan alat tulis untuk mencatat data-data yang didapat.

\section{PROSEDUR PENELITIAN}

Berikut adalah prosedur yang dilakukan dalam penelitian ini:

- Pemilihan Titik Pengukuran

Dalam menentukan titik pengukuran didasari atas beberapa pertimbangan yaitu : 
a) Pada lintasan pengukuran tidak boleh terdapat genangan air diatas permukaan tanah karena dalam pengukuran akan diinjenksikan arus dengan tegangan tinggi pada elektroda yang tertancap di dalam tanah.

b) Memprediksi atau memperkirakan letak terdapatnya dugaan lindi berdasarkan kondisi tanah dan penelitian sebelumnya.

\section{- Metode Pengukuran}

Metode pengukuran yang digunakan dalam pengukuran resistivitas lindi adalah dengan menggunakan metode geolistrik konfigurasi Wenner-Schlumberger. Pada konfigurasi Wenner spasi/jarak semua elektroda dibuat sama sedangkan pada konfigurasi Schlumberger spasi antara dua elektroda potensial dibuat sama akan tetapi dua elektroda arus jaraknya diubah-ubah (diperbesar). Tahap-tahap pengambilan data pengukuran di lapangan adalah sebagai berikut :

a) Menentukan titik lintasan pengukuran dengan menggunakan GPS

b) Menancapkan elektroda A, B, M, dan N pada permukaan tanah dengan spasi yang telah ditentukan sesuai dengan konfigurasinya,

c) Kabel dibentangkan sebagai penghantar arus dan potensial yang menghubungkan antar elektroda dengan alat resistivitymeter.

d) Setelah elektroda terhubung dengan resistivitymeter, maka pengukuran sudah siap dilakukan.

e) Putar pengukur tegangan (i) hingga jarum menunjukan angka 0, lalu tekan tombol dan catat besar tegangan/tahanan (volt/ohm) dan besarnya arus (ampere) yang terjadi.

\section{- Akuisisi Lapangan}

Penelitian ini menggunakan 4 lintasan pengukuran. Lintasan yang 1 berada di sel yang sudah tidak aktif lagi dengan koordinat $00^{\circ} 01,486^{\prime}$ LS dan $109^{\circ} 19,308^{\prime}$ BT - 00 01,515' LS dan $109^{\circ} 19,307^{\prime}$ BT. Lintasan 1 digunakan sebagai lintasan kontrol. Lintasan 2 dan 3 berada dikebun milik warga dengan koordinat lintasan $200^{\circ} 01,409^{\prime} \mathrm{LS}$ dan $109^{\circ} 19,328^{\prime}$ BT $-00^{\circ} 01,435^{\prime} \mathrm{LS}$ dan $109^{\circ} 19,327^{\prime}$ BT. Koordinat lintasan 3 yaitu $00^{\circ} 01,420^{\prime}$ LS dan $109^{\circ}$ 19,329' BT - $00^{\circ} 01,422^{\prime}$ LS dan $109^{\circ} 19,353^{\prime}$ BT. Lintasan 4 berada diwilayah pemukimanan dengan koordinat $00^{\circ} 01,396^{\prime} \mathrm{LS}$ dan $109^{\circ} 19,325^{\prime} \mathrm{BT}-00^{\circ} 01,378^{\prime} \mathrm{LS}$ dan $109^{\circ} 19,308^{\prime}$ BT. Titik pengukuran dapat dilihat pada Gambar 1.


Sumber : DKP Pontianak, 2015

Gambar 1. Sketsa Lokasi dan Lintasan Pengukuran 


\section{ANALISIS DATA}

Analisis data dalam penelitian ini meliputi perhitungan faktor geometri, Resitansi dan nilai tahanan jenis semu. Pengolahan data dilakukan dengan menghitung faktor geometri dari konfigurasi Schlumberger untuk menghilangkan pengaruh letak elektroda potensial terhadap letak kedua elektroda arus. Pengolahan data dari hasil penelitian dibagi dalam tiga tahap, yaitu :

a) Menghitung faktor geometri untuk konfigurasi elektroda Wenner-Schlumberger dengan menggunakan persamaan dibawah ini.

$$
\mathrm{k}=\pi \mathrm{n}(\mathrm{n}+1) \mathrm{a} \text {. }
$$

Dimana

a : jarak spasi

$\mathrm{n} \quad$ : faktor pengali

b) Menghitung nilai resitansi ( $R$ )

$$
\mathrm{R}=\frac{V}{I} \text {. }
$$

$$
\begin{array}{ll}
\text { Dimana } & : \\
\mathrm{R} & \text { : nilai resitansi (ohm) } \\
\mathrm{V} & \text { : tegangan (volt) } \\
\mathrm{I} & \text { : kuat arus (ampere) }
\end{array}
$$

c) Menghitung nilai tahanan jenis semu $(\rho)$

$$
\rho=k \text {. R. }
$$

d) Setelah dilakukan perhitungan nilai tahanan jenis semu (Apparent Resistivity) yang selanjutnya diolah dengan menggunakan software Res2dinv sehingga diperoleh struktur keadaan bawah permukaan daerah yang ditunjukkan oleh perbedaan nilai tahanan jenis dan divisualisasikan dengan perbedaan warna, dari hasil inversi menunjukkan nilai tahanan jenis sebenarnya terhadap kedalaman. Data dari GPS berupa data ketinggian, posisi garis lintang, dan posisi garis bujur diambil untuk mengetahui posisi atau letak daerah penelitian.

\section{HASIL DAN PEMBAHASAN}

\section{A. ANALISA DATA HASIL INVERSI DENGAN SOFTWARE RES2DINV}

Pengolahan data dengan software Res2Dinv didapatkan model tahanan jenis bawah permukaan di sepanjang lintasan, kedalaman lapisan, dan nilai RMS error. Model distribusi tahanan jenis bawah permukaan dapat mencerminkan kondisi bawah permukaan di sepanjang lintasan pengukuran, sehingga dapat dilakukan interpretasi kondisi litologi bawah permukaannya. Penyajian data akan ditampilkan dalam bentuk gambar 2 dimensi dengan menggunakan software Res2dinv seperti pada Gambar 2 menampilkan kondisi bawah permukaan tanah dengan nilai resisistivitas yang berbedabeda tergantung dari material bawah permukaan tanah daerah penelitian.

Hasil inversi pengukuran dilapangan dengan menggunakan software Res2Dinv akan didapat nilai RMSE ( Root Mean Squared Error). Nilai RMSE ini merupakan nilai error yang menunjukkan perbedaan antara nilai resistivitas semu hasil pengukuran dilapangan dan nilai resistivitas semu hasil perhitungan. Menurut Rony (2011) nilai RMSE hasil inversi seminimal mungkin berada dibawah $10 \%$. Dari keempat lintasan pengukuran menunjukkan nilai RMSE berada diatas $10 \%$. Nilai RMSE diatas $10 \%$ cenderung tidak dapat mewakili kondisi sebenarnya di lapangan. Jika nilai RMSE berada dibawah $10 \%$ atau sama dengan $10 \%$ maka dapat dikatakan bahwa data hasil topografi dan nilai resisitivitas yang ditunjukkan telah sesuai dan akurat. Nilai RMSE yang besar disebabkan oleh adanya noise yang merupakan data buruk yang didapatkan pada saat pengukuran di lapangan. 
Menurut Paulus (2012) pada metode resistivity, titik-titik data yang buruk disebut systematic noise dan random noise. Systematic noice ini dikarenakan kegagalan pada saat dilakukan pengukuran dilapangan sehingga pembacaan tidak mempresentasikan nilai pengukuran resistivity sebenarnya. Hal ini bisa terjadi karena adanya kerusakan pada kabel, kontak elektroda dengan tanah yang buruk, menghubungkan kabel ke arah yang salah dan lupa melampirkan klip pada elektroda. Kesalahan pada systematic noise mudah untuk dideteksi dalam alat dan setting data. Sedangkan random noise merupakan noise seperti arus telluric yang mempengaruhi semua pembacaan nilai pengukuran. Hal ini menyebabkan pembacaan pada alat bisa menjadi lebih rendah atau lebih tinggi dari pembacaan yang seharusnya.

Penelitian ini dilakukan pada musim hujan dan jenis tanah pada daerah penelitian merupakan tanah gambut dimana gambut akan menyimpan air hujan dan menjadi lunak atau lembek. Hal ini menyebabkan kontak elektroda terhadap tanah menjadi buruk. Kondisi tanah yang lunak atau lembek menyebabkan elektroda tidak tertancap dengan sempurna. Sehingga elektroda tidak bisa mengalirkan arus listrik yang diinjeksikan kebawah permukaan tanah. Hal ini akan mempengaruhi pembacaan tegangan dan arus listrik pada resistivitymeter, pembacaan pada alat bisa menjadi lebih rendah atau lebih tinggi dari pembacaan yang seharusnya. Untuk memperkecil nilai RMSE pada hasil inversi keempat lintasan pengukuran dilakukan iterasi beberapa kali pada masing-masing lintasan pengukuran. Hasil inversi menunjukkan beberapa nilai resisitivitas yang berbeda. Untuk itu digunakan nilai resistivitas batuan dan bawah permukaan tanah Telfrodd, dkk (1967).

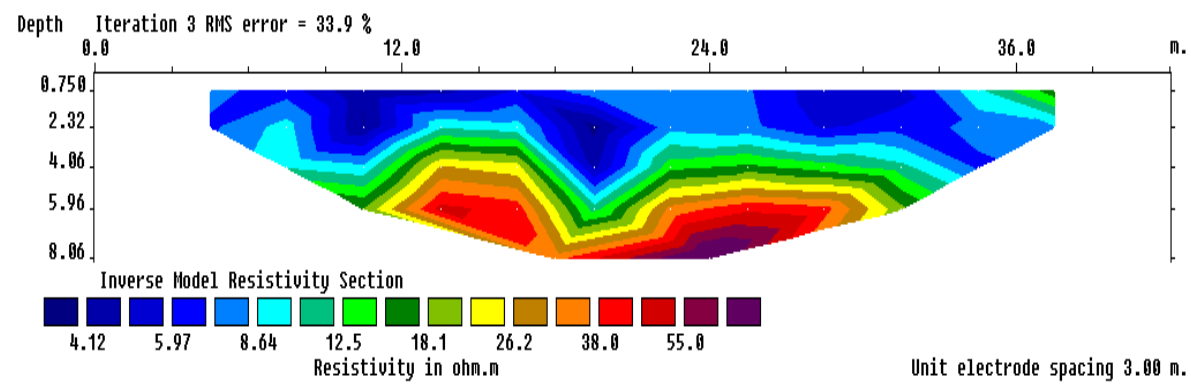

Gambar 2. Hasil Inversi pada Lintasan 1

Lintasan 1 terletak didalam TPA Batu Layang Pontianak tepatnya berada pada sel TPA Batu Layang yang sudah tidak aktif lagi dengan titik koordinat $00^{\circ} 01,486^{\prime} \mathrm{LS}$ dan $109^{\circ}$ 19,308' BT - $00^{\circ} 01,515^{\prime}$ LS dan $109^{\circ} 19,307^{\prime}$ BT. Lintasan 1 ini sebagai kontrol untuk melihat arah sebaran lindi. Nilai resistivitas semu dugaan lindi berdasarkan penelitian Grandis dan Yudisitira (2010) adalah dibawah 10 ohm.m. Pada Gambar 2. nilai resistivitas semu dugaan lindi adalah 4,12-8,64 ohm.m. Dugaan lindi pada lintasan 1 tersebar dimulai pada jarak 4,5-37,5 $\mathrm{m}$ hingga mencapai kedalaman 4,06 $\mathrm{m}$ dari atas permukaan tanah pada lintasan pengukuran.

Berdasarkan Peta Hidrogeologi Indonesia (2004) komposisi litologi batuan didaerah Kalimantan Barat merupakan sedimen lepas yang terdiri dari pasir, batu kerikil, dan tanah lempung. Dari tabel Telfrodd, dkk (1967), bagian sedimen lepas nilai resisitivitas pasir 1$10^{3}$ ohm.m dan lempung $1-10^{2}$ ohm.m. dari tabel nilai resistivitas Telfrodd, dkk (1967) menunjukkan nilai resisitivitas air dalam aluvial sebesar $10-30 \mathrm{ohm} . \mathrm{m}$ dan nilai resistivitas pasir dan kerikil mengandung air tawar 50-500 ohm.m. Pada lintasan 1 nilai resistivitas $12,5-55,0$ ohm.m merupakan nilai resistivitas lempung beserta pasir dan kerikil yang mengandung air tawar. 




Gambar 3. Hasil Inversi pada Lintasan 2

Lintasan 2 berada didepan pintu masuk TPA Batu Layang dengan titik koordinat $00^{\circ}$ $01,409^{\prime} \mathrm{LS}$ dan $109^{\circ} 19,328^{\prime} \mathrm{BT}-00^{\circ} 01,435^{\prime} \mathrm{LS}$ dan $109^{\circ} 19,327^{\prime} \mathrm{BT}$. Dugaan lindi terdapat pada jarak 6-10,5 m dari titik nol pengukuran dengan kedalaman mencapai 2,74 $\mathrm{m}$ dapat dilihat pada Gambar 3. Nilai resistivitas semu dugaan lindi pada lintasan 2 sebesar 6,208,54 ohm.m. Dalam tabel Telfrodd, dkk (1967), menunjukkan nilai resistivitas campuran pasir dan kerikil mengandung air tawar 50-500 ohm.m. Pada lintasan dua, nilai resistivitas $11,8-58,3$ ohm.m merupakan campuran air tanah, pasir dan kerikil, serta lempung.

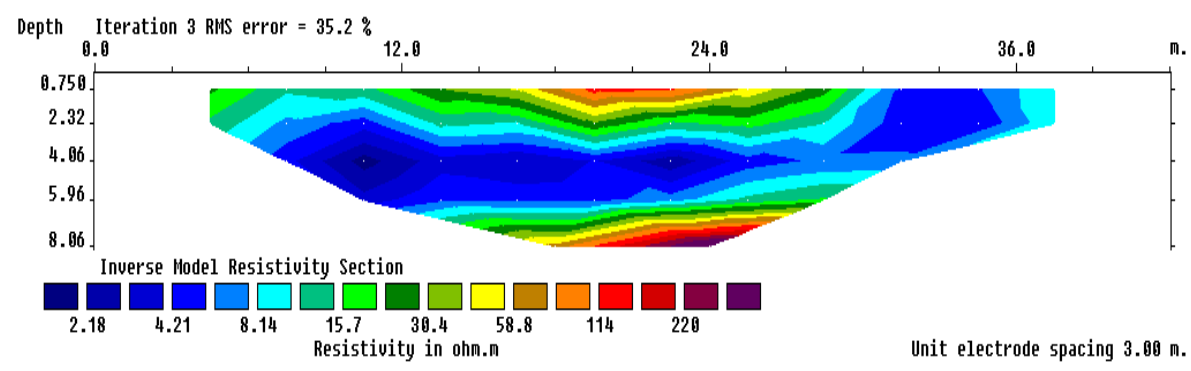

Gambar 4. Hasil Inversi pada Lintasan 3

Lintasan ketiga berada dikebun milik warga didepan pintu masuk TPA Batu Layang dengan titik koordinat yaitu $00^{\circ} 01,420^{\prime} \mathrm{LS}$ dan $109^{\circ} 19,329^{\prime} \mathrm{BT}-00^{\circ} 01,422^{\prime} \mathrm{LS}$ dan $109^{\circ}$ 19,353' BT. Dugaan lindi pada lintasan 3 berada pada jarak 5,25-37,5 m titik nol pengukuran lintasan dengan kedalaman sebaran dugaan lindi mencapai 5,9 m. Sebaran dugaan lindi dapat dilihat pada Gambar 4. Nilai resistivitas semu dugaan lindi pada lintasan 3 sebesar 2,18-8,14 ohm.m. Nilai resistivitas campuran air tanah, pasir, kerikil dan lempung berkisar antara 15,7-220 ohm.m.

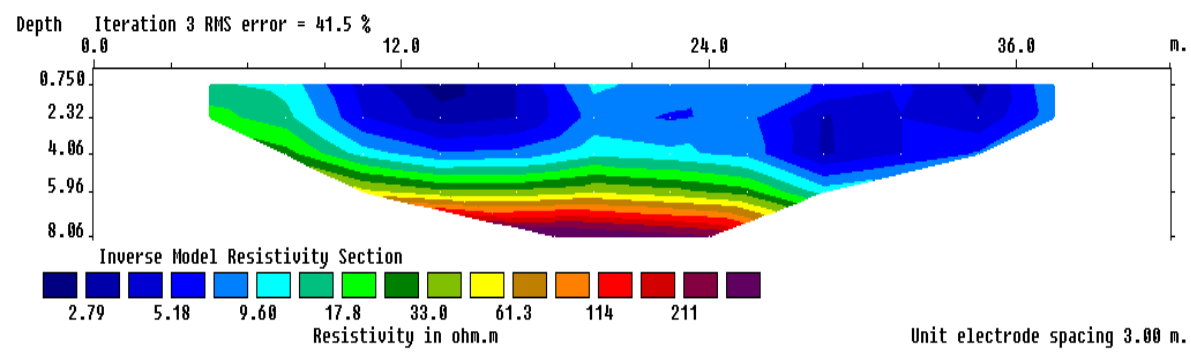

Gambar 5. Hasil Inversi pada Lintasan 4

Hasil inversi pada lintasan 4 dapat dilihat pada Gambar 5. lintasan ini berada diwilayah pemukiman warga dengan titik koordinat $00^{\circ} 01,396^{\prime} \mathrm{LS}$ dan $109^{\circ} 19,325^{\prime} \mathrm{BT}-00^{\circ} 01,378^{\prime}$ LS dan $109^{\circ} 19,308^{\prime}$ BT. Lintasan 4 merupakan lintasan diagonal dengan titik awal lintasan berada dekat dengan pemukiman warga. Nilai dugaan resistivitas semu dugaan lindi pada lintasan 4 sebesar 2,79-9,60 ohm.m. Pada lintasan 4 sebaran lindi berada pada jarak 9 - 
$36 \mathrm{~m}$ dengan kedalaman mencapai 4,06 m. 12,8 - 175 ohm.m merupakan nilai resistivitas untuk pasir, kerikil, lempung yang mengandung air tanah.

Dari keempat lintasan dalam penelitian ini, sebaran lindi secara vertikal mencapai pada kedalaman 5,9 m pada lintasan 3. Sebaran lindi secara dominan ke arah horizontal daripada vertikal hal ini disebabkan oleh lindi yang menyebar mengikuti pergerakan air tanah.

\section{B. Sebaran Air Lindi}

Salah satu aspek penting dalam pengelolaan sampah padat perkotaan adalah masalah lindi yang jika dalam pengelolaannya tidak baik akan menyebabkan ancaman serius bagi lingkungan, karena produksi lindi akan memasuki aliran air bawah tanah dan juga air permukaan. Lindi adalah cairan yang mengalir atau larut dari TPA, dengan komposisi yang bervariasi tergantung dari usia TPA dan jenis limbah yang terkandung didalamnya. Lindi biasanya mengandung bakteri terlarut atau dan bakteri yang tidak terlarut (Azhar, 2008).

TPA Batu Layang telah beroperasi sejak tahun 1996 dengan sistem open dumping dimana sampah yang masuk ke TPA akan ditumpuk pada sel yang telah disediakan dengan tinggi yang telah direncanakan, lalu ketika sel sudah pada batas maksimum menampung sampah akan ditutup dengan tanah penutup. Dampak yang ditimbulkan dari aktivitas ini akan berpengaruh terhadap kualitas air tanah dangkal yang diakibatkan karena adanya rembesan air lindi.

Gambar 2. menunjukkan pada lintasan 1 yang digunakan sebagai kontrol dalam penelitian ini dan terletak pada sel TPA Batu Layang yang sudah tidak aktif lagi. Berdasarkan hasil inversi ditemukan adanya dugaan rembesan lindi yang menyebar secara horizontal dan vertikal dengan nilai resistivitas semunya berada dibawah 10 ohm.m. Sebaran lindi pada lintasan 1 ini diduga karena adanya limpasan air hujan (run off) yang masuk melalui tanah penutup diatas sel sehingga melarutkan zat organik dan anorganik.

Menurut Pohland dan Harper (1998) infiltrasi air hujan dapat membawa kontaminan dari tumpukan sampah dan memberikan kelembaban yang dibutuhkan bagi proses penguraian biologis dalam pembentukan air lindi. Meskipun sumber dari kelembabannya mungkin dibawa oleh sampah masukannya, tetapi sumber utama dari pembentukan air lindi ini adalah adanya infiltrasi air hujan. Jumlah hujan yang tinggi dan sifat timbunan yang tidak solid akan mempercepat pembentukan dan meningkatkan kuantitas air lindi yang dihasilkan.

Musim hujan akan memberi pengaruh yang besar terhadap lindi. Fungsi air hujan adalah sebagai pengencer, sehingga lindi akan mudah terangkut bersama-sama dengan limpasan air hujan dan dapat merembes masuk ke badan air mengalir secara gravitasi mengikuti topografi daerah tersebut. Lindi bersifat toksik tentunya akan menyebabkan dampak negatif terhadap lingkungan sekitar. Menurut Asdak (2007) Tinggi muka air tanah bukan suatu permukaan air yang bersifat statis. la berfluktuasi, naik dan turun tergantung pada fluktuasi curah hujan .

Lintasan 2 ditunjukkan pada Gambar 3.menunjukkan adanya dugaan lindi dengan nilai resistivitas semu sebesar $6,20-8,54 \mathrm{ohm}$.m. Secara vertikal sebaran dugaan lindi mencapai 2,74 m. Menurut Dong (2009) umumnya, migrasi lindi dari TPA berpotensi mencemari air tanah karena lindi akan merembes dalam tanah kemudian menyebar mengikuti aliran air tanah.

Gambar 4. menunjukkan dugaan lindi berada pada kedalaman 0,75 - 5,9 m. Menurut Irham (2006) resapan air hujan kedalam air tanah akan dipengaruhi oleh jenis batuan penyusun lapisan tanah tersebut. Sifat atau kemampuan porositas dan permeabilitas tanah dikendalikan oleh granulometrik batuan penyusunnya. Makin kasar 
butiran makin besar pula kemungkinan untuk bersifat permeable. Daya serap antara batuan satu dengan lainnya juga akan berbeda, hal ini tergantung dari jenis tekstur dan struktur dari masing-masing batuan tersebut. Struktur batuan yang berpengaruh terhadap resapan air serta akuifer adalah pada struktur batuan sedimen. Dengan adanya struktur batuan akan mempengaruhi pola aliran muka air tanah di samping topografi. Berdasarkan peta hidrogeologi tahun 2004 komposisi batuan litologi untuk daerah Pontianak adalah sedimen lepas atau setengah padu, umumnya berukuran lempung hingga kerakal. Kelulusan rendah sampai sedang, berkelulusan tinggi pada material kasar.

Air lindi yang berada di permukaan tanah dapat menimbulkan polusi pada air tanah dan air permukaan, hal ini dikemukakan oleh Ehrig (1993) :

1. Air permukaan yang terpolusi oleh air lindi dengan kandungan zat organik tinggi, pada proses penguraian secara biologis akan menghabiskan kandungan oksigen dalam air dan akhirnya seluruh kehidupan dalam air yang tergantung oleh keberadaan oksigen terlarut akan mati.

2. Air tanah yang terpolusi oleh air lindi dengan konsentrasi tinggi, polutan tersebut akan berada dan tetap ada pada air tanah tersebut dalam jangka waktu yang lama, karena terbatasnya oksigen terlarut sehingga sumber air yang berasal dari air tanah tidak sesuai lagi untuk air bersih.

Menurut Asdak (2007) ketika air hujan jatuh diatas permukaan tanah, tergantung pada kondisi biofisik permukaan tanah, sebagian atau seluruh air hujan tersebut akan mengalir masuk ke dalam tanah melalui pori-pori permukaan tanah. Proses mengalirnya air hujan ke dalam tanah disebabkan karena adanya tarikan gaya gravitasi dan gaya kapiler tanah. Dibawah pengaruh gaya gravitasi, air hujan mengalir vertikal kedalam tanah melalui profil tanah. Pada sisi yang lain, gaya kapiler bersifat mengalirkan air tersebut secara tegak lurus ke bawah dan ke arah horizontal (lateral). Dalam perjalanan tersebut, air juga mengalami penyebaran ke arah lateral akibat tarikan gaya kapiler tanah, terutama ke arah tanah dengan pori-pori yang lebih sempit dan tanah lebih kering.

Suwendi (2011) melakukan penelitian mengenai kajian penyebaran limbah logam berat kadmium (Cd) pada air tanah bebas di sekitar TPA Batu Layang. Berdasarkan dari hasil penelitian yang dilakukan oleh Suwendi kadar kadmium berada diatas batu muku yang telah ditentukan yaitu $1,1667 \mathrm{mg} / \mathrm{l}$. Hasil penelitian yang dilakukan oleh Menas Aswan (2014) yang melakukan penelitian sebaran polutan TPA Batu Layang dengan menggunakan EM Conductivity dimana sebaran air lindi sejauh $47 \mathrm{~m}$ dari titik awal pengukuran.

Dari keempat lintasan pengukuran pada penelitian ini menunjukkan bahwa dugaan sebaran lindi mengalir dari arah utara ke selatan dan sudah mencapai pemukiman penduduk sejauh $156 \mathrm{~m}$ dari TPA Batu Layang Pontianak. Hasil inversi yang dilakukan dengan software Res2Dinv menunjukkan dugaan lindi mengalir secara vertikal dan horizontal (lateral).

\section{UPAYA MENGATASI SEBARAN AIR LINDI}

Permasalahan pencemaran air tanah oleh lindi disebabkan metode pengelolaan TPA yang belum memadai. Secara umum, faktor penyebab pencemaran adalah pemilihan lokasi TPA yang tidak sesuai dengan kriteria teknis yang berlaku sesuai SNI No 03-32411994, keterbatasan sarana dan prasarana pengelolaan sampah, sistem operasi pengelolaan akhir yang lebih cenderung dilakukan secara open dumping, dan penanganan pasca operasi yang belum memadai (Setyaningrum, 2002).

Sebaran lindi harus dapat diatasi karena jika dibiarkan akan mencemari air tanah dangkal dan tanah di sekitar TPA Batu Layang yang akan berdampak negatif terhadap 
lingkungan dan kesehatan manusia. Untuk itu diberikan upaya untuk mengatasi sebaran lindi berupa rekomendasi kepada pengelola TPA Batu Layang yaitu:

\section{- Sistem Drainase}

Perencanaan sistem drainase pada TPA bertujuan agar limpasan air hujan (run off) tidak mengalir kedalam landfill. Jika limpasan air hujan mengalir ke daerah landfill akan menyebabkan volume lindi bertambah karena adanya proses pengenceran dengan air hujan dan mencemari air tanah dan tanah disekitar areal TPA. Perencanaan sistem drainase didalam TPA ini meliputi fasilitas jalan TPA, kantor, sel, dan bagian fasilitas lainnya. Pada sel TPA yang sudah tidak aktif lagi perlu diperhatikan kemiringan tanah penutup. Kemiringan tanah penutup mengarah pada badan drainase hal ini bertujuan agar air hujan akan mengalir ke drainase.

\section{- Lapisan Kedap Air}

Menggunakan lapisan kedap air disekeliling dan dasar sel TPA. Hal ini bertujuan untuk memperkecil kemungkinan air lindi akan merembes keluar. Tanah lempung dapat digunakan sebagai lapisan kedap air karena tanah lempung merupakan tanah yang sulit menyerap air. Selain menggunakan tanah lempung, juga dapat menggunakan lapisan kedap air dari bahan sintesis.

\section{- Pipa-pipa penyalur lindi}

Pembangunan pipa-pipa penyalur lindi ini agar lindi yang dihasilkan tidak bergabung dengan air hujan didalam drainase. Karena jika bergabung akan terjadi pengenceran serta kapasitas drainase menjadi berkurang. Pipa-pipa lindi ini berada didasar sel diatur dengan kemiringan tertentu agar lindi dapat mengalir menuju kolam pengolahan.

\section{- Buffer Zone}

Berdasarkan data dari DKP Kota Pontianak, luas lahan TPA Batu Layang sebesar 26,6 ha dan sisa lahan yang belum digunakan sebesar 5 ha. Sisa lahan yang belum digunakan ini dapat dimanfaatkan untuk buffer zone. Buffer zone untuk menghindari dampak dari bau, kebisingan, lalat dan vektor penyakit. dengan ditanami pohon pelindung dengan ketebalan berkisar antara $20 \mathrm{~m}$ sampai dengan $50 \mathrm{~m}$ dari batas luar daerah operasional TPA yang didukung dengan penanaman jenis pohon yang cepat tumbuh dalam waktu 1 tahun mencapai $4 \mathrm{~m}$, dan tidak mudah patah akibat pengaruh angin misalnya sengon, mahoni, tanjung dan lain-lain dengan kerapatan/jarak antar pohon $2 \mathrm{~m}$. Selain itu ditetapkan pula Free Zone yang merupakan zona bebas dimana kemungkinan masih dipengaruhi leachate, sehingga harus merupakan Ruang Terbuka Hijau (RTH) dan apabila dimanfaatkan disarankan bukan merupakan tanaman pangan, dengan ketebalan 50 sampai dengan $80 \mathrm{~m}$ dari batas luar buffer zone, sehingga TPA sampah dapat difungsikan secara terpadu dengan pengelolaannya (Hermanto, 2007).

\section{KESIMPULAN}

Berdasarkan hasil penelitian yang telah dilakukan, dapat disimpulkan bahwa dari hasil interpretasi data pengukuran dilapangan menunjukkan adanya dugaan sebaran lindi dengan nilai resisitivitas dibawah $10 \mathrm{ohm}$.m masuk ke pemukiman masyarakat sejauh 156 $\mathrm{m}$ dari TPA Batu Layang Pontianak ke arah selatan.

\section{UCAPAN TERIMA KASIH}

Dengan selesainya penelitian ini saya mengucapkan terima kasih yang sebesar-besarnya kepada Allah SWT., kedua orang tua, kedua dosen pembimbing yaitu Bapak Dr. Ir. Marsudi, M. Sc dan Bapak H. Kiki Prio Utomo, ST., M.Sc serta kepada teman-teman Teknik Lingkungan 2011, seluruh teman-teman Fakultas Teknik Untan dan semua orang yang 
telah berperan dalam membantu penelitian ini yang tidak dapat diucapkan satu persatu. Harapan saya penelitian ini dapat bermanfaat bagi semua dan dapat dipergunakan sebagaimana mestinya.

\section{DAFTAR PUSTAKA}

Asdak, C. 2007. Hidrologi dan Pengelolaan DAS (cetakan keempat). UGM Pers. Yogyakarta.

Azwar, A. 2008. Pengantar Ilmu Kesehatan Lingkungan. Mutiara Sumber Widya. Jakarta Damanhuri, E. 1995. Teknik Pembuangan Akhir (TPA). Diktat Kuliah. TL-ITB

Dinas Kebersihan dan Pertamanan Kota Pontianak. 2013. Komposisi Sampah TPA Batu Layang dan Layout TPA Batu Layang

Dong, S., Z. Tang, and B. Lui. 2009. Numerical Modeling of Environment Impact of Landfill Leachate Leakage on Groundwater Quality- A Field Application. International Conference on Environmental Science. ESIAT 09, pp. 565-568.

Ehrig, H. J. 1993. Quality and quantity of sanitary landfill air air lindi. Wastewater management research.

Grandis, H. dan Yudistira,T. 2000. Studi Pendahuluan Identifikasi Penyebaran Polutan Bawah Permukaan Menggunakan Metode Geolistrik. Himpunan Ahli Geofisika Indonesia (HAGI). Jakarta

Hermanto A, Dardak. 2007. Kebijakan Penataan Ruang Untuk Pengelolaan Persampahan. Pusat Kajian Strategis Pembangunan Nasional. Jakarta

Humala P, Rony. 2011. Studi Sebaran Air Limbah Sampah Bagian Utara TPA Bantar Gebang Dengan Metode Resistivity Wenner-Sclumberger. UI. Jakarta

Irham. M, 2006. Pemetaan Sebaran Air Tanah Asin Pada Akuifer Dalam di Wilayah Semarang Bawah. http://eprints.undip.ac.id/2139/1/.pdf

Iqbal, M. A. and S. G. Gupta. 2009. Studies on Heavy Metal Ion Pollution of Groundwatersources as An Effect of Municipal Solid Waste Dumping. African Journal of Basic and Applied Sciences. Vol. 1, No. 5-6 : 117-122.

Menas, Aswan. 2014. Studi Rembesan Polutan Sampah Berdasarkan Metode Konduktivitas Elektromagnetik di Sekitar Tempat Pembuangan Akhir (TPA) Batu layang Kota Pontianak. Jurnal FMIPA UNTAN

Paulus, 2012 . Pemodelan 3D Cavity Daerah " $x$ " Dengan Menggunakan Metode Resistivity Konfigurasi Dipole-Dipole

Pohland, F. G., \& Harper, S. R. 1985. Critical review and summary of leachate and gas production from landfills. Washington: EPA

Setyaningrum, E. 2002. Pola Penyebaran Pencemaran Lindi Terhadap Air Tanah di Sekitar Landfill (Studi Kasus: TPA Bantar Gebang, Bekasi). Tesis Progam Magister Teknik Lingkungan. Institut Teknologi Bandung.

Suwendi. 2008. Kajian Penyebaran Logam Berat Raksa dan Kadmium Pada Air Tanah Bebas Di Selatan TPA Kota Pontianak

Wardhana, W.A. 2001. Dampak Pencemaran Lingkungan. Penerbit Andi Offset.Yogyakarta 